\title{
QUALITY OF CONTINUOUS PROFESSIONAL DEVELOPMENT FOR AUTOMOTIVE ENGINEERING PRODUCTIVE TEACHERS
}

\author{
Dwiki Muda Yulanto ${ }^{1}$, Putu Sudira $^{2}$, and Pramudya Dwi Aristya ${ }^{3}$ \\ ${ }^{12}$ Department of Technological and Vocational Education, Universitas Negeri Yogyakarta, Indonesia \\ ${ }^{3}$ Graduate School of Science and Technology, Shizuoka University, Japan \\ E-mail: dwiki.muda2016@student.uny.ac.id
}

\begin{abstract}
The $21^{\text {st }}$ century becomes a new challenge for productive teachers in developing their competency. One of the methods for developing their competency is conducting a continuous professional development program. This study was aimed at describing the quality of the continuous professional development of Automotive Engineering productive teachers. The type of this study was a survey study which used a descriptive quantitative method. The research subjects were all of the productive teachers of Automotive Engineering in Surakarta city with the total of 76 teachers. In conducting the study, a questionnaire was used as the data collection technique. Data analysis techniques consisted of editing, tabulating, analyzing and interpreting, and concluding. The results showed the quality of the continuous professional development of Automotive Engineering productive teachers in Surakarta city was categorized as low with the percentage of 59.2\%. In conclusion, productive teachers of Automotive Engineering in Surakarta city did not actively participate in continuous professional development. The implications of this study showed that the teachers must increase self-awareness to do continuous professional development.
\end{abstract}

Keywords: automotive engineering, continuous professional development, productive teachers

\section{INTRODUCTION}

A vocational high school is a school designed to prepare its students and its graduates to be ready to enter the workforce and have the ability to develop a professional working attitude in their respective field. The $21^{\text {st }}$ century has the work of the world with extremely different characteristics compared to the previous period. All of the fields of work have applied digitalization and automation. Many of the jobs with the repetitive characteristics previously done by human are starting to be replaced by machines, both production machines, and computers. A lot of industry use machines and robots that can do the complicated job tasks, share information, or even send and receive commands automatically without human's participation. All of the production processes work with the internet connection as the primary support. All of the objects are completed by technology devices supported by a sensor that can communicate on its own. All of the things mentioned the effect on the work demand and the need for the students' competency. The students are required to have skills, knowledge, and the ability in technology, media, and information, learning skills, innovation as well as life and career's skills [1].

Productive teachers must be able to guide the students in mastering the knowledge, skills, attitude, and value that are needed in the workplaces. For that reason, teachers must have qualified knowledge and skills. There is still deficiency faced by the productive teachers. Surakarta city achieved the $3^{\text {rd }}$ rank on the Competency Teacher Exam among all the cities in Central Java in 2015 with the average score of 62.34. Despite the high rank, the average score is still categorized as low where among 10.900 teachers, $42 \%$ of them still received scores below the defined standard, which is 55 . Based on the statistics, 831 participants are Vocational High School teachers. It can be defined that those 831 teachers, who work in both the public and private school are still not qualified as the professional teacher. The obstacles faced by them are including the lack of mastery the pedagogic competency and the computer usage ability. The result shows that the competency owned by the vocational school 
teacher is still low [2]. The result of a study done in a vocational high, SMK Negeri 2 Pengasih, the teaching-learning process in automotive engineering productive subject still did not meet the expectation yet. The productive teacher was not able to use the learning media functionally, he/she still used the lecture method and wrote notes in the whiteboard, and he/she was still not able to manage the class maximally [3].

Teachers' role in the $21^{\text {st }}$ century is to encourage their students to become superior individuals who can survive and compete with others. A professional teacher is required for implementing this duty. Teachers are always required to elevate their quality under their function and their role. As a profession, a teacher must develop their professionalism through a program called continuous professional development. It is a program which is implemented under the needs, gradually, continuously to improve teachers' professionalism [4]. The real action done by the government in improving productive teachers' competency is issuing a Presidential Instruction Number 9 Year 2016 about the Revitalization of Vocational High Schools to improve Indonesian Human Resources' Quality and Competitiveness.

Along with this instruction, the Ministry of Education and Culture instructed to increase the number of vocational educators and education staffs as well as their competency. The government through the Ministry of Education and Culture mustto be implemented namely Vocational High School teachers' development. A continuous professional development program is directed to decrease the gap among knowledge, skills, social competency, and personality owned by teachers today with demands in the future related to their profession. Teachers should be active in the continuous professional development to improve their competency [5]. Continuous professional development is one of the methods to improve teachers' professionalism, efficiency, and effectiveness of teaching [6]. Continuous professional development will develop teachers' knowledge, discipline, skills, attitudes, and t values [7].

Vocational High School teachers must have higher awareness for elevating self-quality and improving competency as well as profession. Teachers' professional development is one of the media to strengthen selfcompetency in executing profession as a professional teacher [8]. There were several facts of continuous professional development which have done by teachers. Santoso [9] showed that the program implementation done by teachers was categorized as very good. It was achieved because of the high level of awareness owned by teachers in developing their profession. However, some program implementation was still not maximal. Alifa [10] described that the quality of continuous professional development was $92.2 \%$ in the low category. In line with the previous statement, the research result in some Vocational High School in Purworejo area shows that Automotive Engineering teacher's continuous professional development is still categorized as low. It means that only a few teachers did a self-development investment, scientific publication, and made an innovative working activity [11]. It is interesting for remembering that the government's effort through this program could not be implemented maximally by all the teachers. If the continuous professional development program is connected with teachers' performance, it will turn out well and give the positive impact on their performance. There are significant impacts on teachers' professional development. Teachers' professional development is aimed at creating teachers' independence so that they can actualize themselves for implementing education which has a good quality, as well as improving the teachers' performance [12].

At present the quality of continuous professional development which was done by Automotive Engineering productive teachers in Surakarta City is unknown. Therefore, this study focuses on the activities of continuous professional development which carried out by the productive teachers of Automotive 
Engineering in Surakarta city. The results of this study can show the condition of continuous professional development done by Automotive Engineering productive teachers in Surakarta city so that they can determine what actions should be taken related to the continuous professional development carried out by Automotive Engineering productive teachers in Surakarta City.

\section{METHOD}

This study was a survey study with descriptive quantitative method. The study was conducted in ten Vocational High Schools in Surakarta which have the Expertise Program of Automotive Engineering. The population consisted of all of the productive teachers who teach Automotive Engineering in Surakarta city with a total of 76 teachers. The sample determination used a saturation sample method where all of the population members were categorized as the sample. Besides, a questionnaire was used as the research instrument to collect the data.

In validating the instrument, expert judgment was used, while in establishing the instrument reliability, an internal consistency method with Cronbach's Alpha was used. The questionnaire consisted of 100 questions with four alternative answers namely always, often, sometimes, and never.. Data analysis technique consisted of editing, tabulating, analyzing and interpreting, as well as concluding. The identification process used a frequency distribution table, Mean Ideal (Mi), and Ideal Deviation Standard (SDi). From the calculations, it was divided into three categories namely high, average, and low. The research flow is presented in Figure 1.

\section{RESULTS AND DISCUSSION}

This study describes the quality of productive teachers' continuous professional development for Automotive Engineering in Surakarta city. The continuous professional development program consisted of selfdevelopment, scientific publication, and innovative working activity. The data revealed the quality of the self-development program of Automotive Engineering teachers who teach in Surakarta city. Among all participants, only six respondents were categorized high with the percentage of $9 \%$. For the average category, it is $66 \%$ with the total of 50 respondents. The low category reached $25 \%$ with 19 respondents. The statistics showed the productive teachers' quality in self-development activity was categorized as average or less active. The productive teachers also had low participation in functional training and teachers' collective activities. Figure 2 presents the quality of automotive engineering productive teachers in self-development in Surakarta city.

The data analysis results in term of scientific publication activity shows that is no one is categorized as high. The average category has only 5\% percentage with four respondents. Meanwhile, $95 \%$ of the population is categorized as the low category with 72 respondents. Data showed that the quality of productive teachers in publishing scientific reports was really low. The scientific publication includes presentations in a scientific forum. In short, teachers' participation in doing this activity was still really lacking. This can be seen in Figure 3.

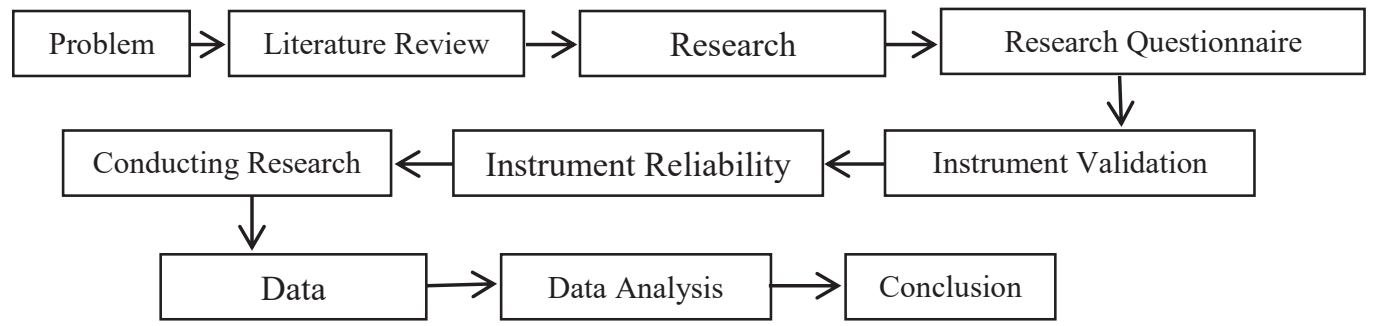

Figure 1. Research Flow Scheme 


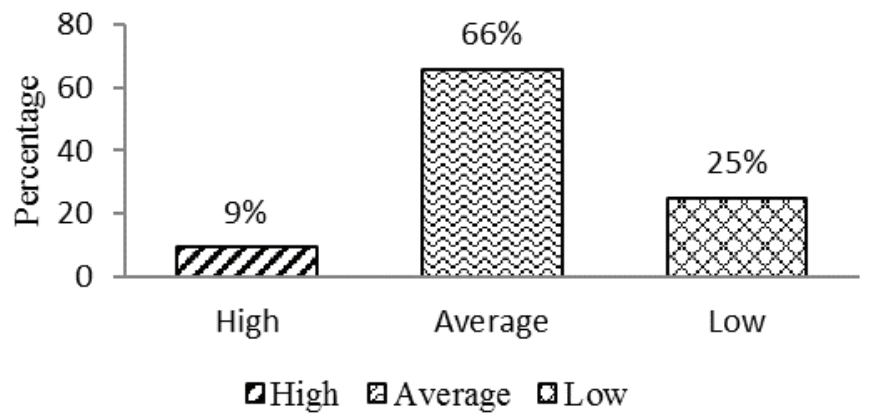

Figure 2. Quality of Automotive Engineering Productive Teachers in Self-Development in Surakarta City

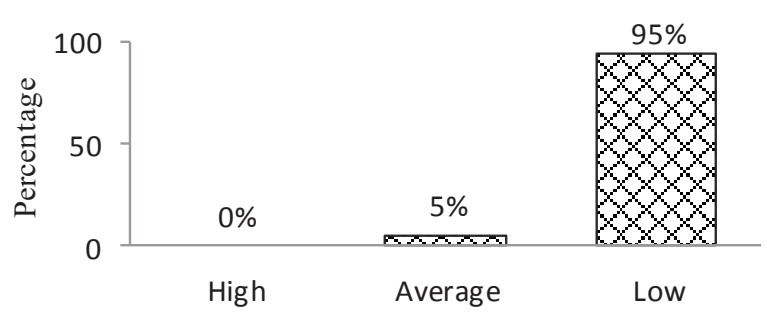

High Average $\square$ Low

Figure 3. Quality of Automotive Engineering Productive Teachers Percentage in Scientific Publication Activity in Surakarta City

The data analysis about the innovative working activity which has done by productive teachers of Automotive Engineering in Surakarta shows that there is none who is categorized as high. The average category is $60 \%$ with 46 respondents. Meanwhile, the low category reaches $40 \%$ with 30 respondents categorized in this category. The data show that teachers' quality in conducting the innovative working activity is categorized as average or less active. The productive teachers are less active in the discovery of appropriate technology, learning development, guiding and questioning standards. The quality of the teachers in innovative working activity is presented in Figure 4.

If the data analysis is done for all of the activities in this program, the result shows that no one is categorized into a high category. The category of average is $41 \%$ with 31 respondents. Meanwhile, the low category has the highest percentage with $59 \%$ with 45 respondents. All the statistics mentioned show that the productive teachers' efforts in the continuous professional development program are categorized into a low category or in other words, they are indeed less active in the program. The Quality of Automotive Engineering productive teachers in the continuous professional development program in Surakarta city can be seen in Figure 6.

Teachers' participation in the continuous professional development program is influenced by many factors. Good awareness of teaching-learning activity affects the teachers' activity in the program. Teachers must have a strong belief that by following this program, it will not affect only teachers' quality, but it will also affect the students' success. The greater teachers' participation is, the students' interest to the teacher is getting higher [13]. The time difficulty, the limited funds, and the less trained staff are the obstruction that is found in the program's implementation [14]. 


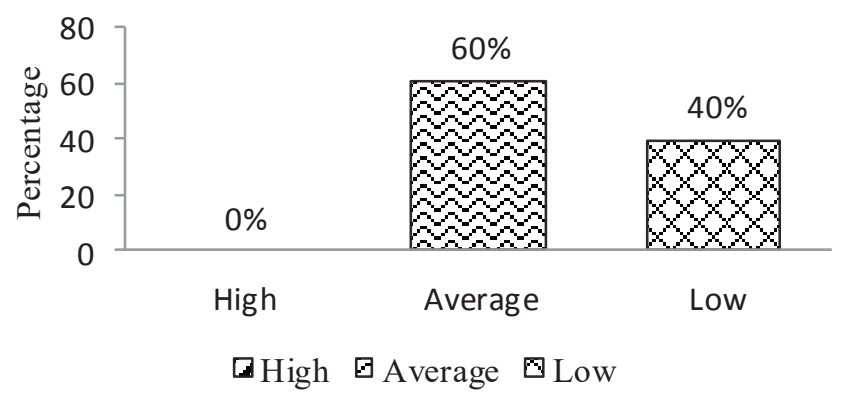

Figure 4. Quality of Automotive Engineering Productive Teachers in Innovative Working Activity in Surakarta City

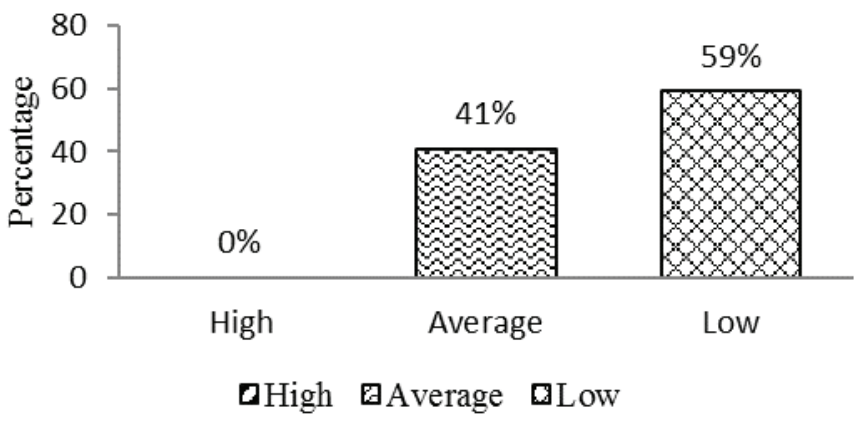

Figure 5. Quality of Automotive Engineering Productive Teachers in Continuous Professional Development Program in Surakarta City

Government's role and the role of evaluation can influence the program development. The government must always fully support this program so that the program can be maximally executed. After the teachers followed this program, there must be an evaluation to know the strong program rate [15]. For the teachers who followed this program, there were also the advantages that can be taken, including helping them in improving their competency, becoming a promotional instrument for their career in their profession, as well as facilitating to develop someone's professional identity [16].

\section{CONCLUSION}

The quality of productive teachers' continuous development program for Automotive Engineering in Surakarta city is categorized in a low category with the percentage of $59 \%$. This program consists of three activities including self-development, scientific publication, and innovative works. Teachers' self-development quality is categorized as average with the percentage of $66 \%$. Furthermore, teachers' scientific publication activity is at a low level with the percentage of $95 \%$. Lastly, teachers' innovative works reach $60 \%$ for the average category. This indicates that an evaluation for the productive teachers' continuous development program is required for productive teachers of Automotive Engineering in Surakarta city to identify the obstructions faced when implementing the program.

\section{REFERENCES}

[1] B. Trilling and C. Fadel, 21st Century Skills: Learning for Life in Our Times. San Francisco: Jossey-Bass A Wiley Imprint, 2009.

[2] F. R. Wardhani, "Analisis Kompetensi Guru Berbasis Uji Kompetensi Guru 
(UKG) Pada Guru SMK Bidang Keahlian Administrasi Perkantoran di Surakarta Tahun Ajaran 2015/2016," J. Inf. Dan Komun. Adm. Perkantoran, vol. 2, no. 1, pp. 75-84, 2017.

[3] R. Saputra, "Kesulitan yang Dihadapi Guru Mata Pelajaran Produktif Jurusan Otomotif di SMK N 2 Pengasih Ditinjau dari Aspek Penggunaan Media Pembelajaran dan Pemanfaatan TIK,' Universitas Negeri Yogyakarta, 2014.

[4] Department of National Education, "Peraturan Menteri Negara dan Pendayagunakan Aparatur Negara dan Reformasi Birokrasi Nomor 16 Tahun 2009 tentang Jabatan Fungsional Guru dan Angka Kreditnya," Jakarta, 2009.

[5] C. Dyah and S. Indrawati, "Continuous Professional Development to Improve theTeachers'Competencies,"Proceeding 2nd Int. Conf. Teach. Train. Educ., vol. 2, no. 1, pp. 656-663, 2016.

[6] G. Chikari, N. Rudhumbu, and D. Svotwa, "Institutional Continuous Professional Development as a Tool for Improving Lecturer Performance in Private Higher Education Institutes in Botswana," Int. J. High. Educ. Manag., vol. 2, no. 1, pp. 26-39, 2015.

[7] W. Engelbrecht and P. Ankiewicz, "Criteria for Continuing Professional Development of Technology Teachers' Professional Knowledge: A Theoretical Perspective," Int. J. Technol. Des. Educ., vol. 26, no. 2, pp. 259-284, 2016.

[8] I. W. Djatmiko, "A Study on The Empowering Teachers' Professional Development and Quality Assurance to Increase Teachers' Effectiveness In Vocational Secondary Schools," J. Pendidik. Teknol. dan Kejuru., vol. 23, no. 2, pp. 144-151, 2016.
[9] D. Santoso, "Need Assessment Pengembangan Keprofesionalan Berkelanjutan Guru Smk Teknik Audio Video," J. Pendidik. Teknol. dan Kejuru., vol. 22, no. 2, pp. 148-154, 2014.

[10] U. N. Alifa, "Kualitas Pengembangan Profesi Guru di SMK Muhammadiyah 1 Wates," Universitas Negeri Yogyakarta, 2017.

[11] A. Susanto, "Pelaksanaan Pengembangan Keprofesian Ber-kelanjutan (PKB) Pada Guru SMK Teknik Otomotif di Wilayah Purworejo," in Seminar Pendidikan Nasional, 2016, pp. 45-57.

[12] A. D. K. Putri and N. Imaniyati, "Pengembangan Profesi Guru Dalam Meningkatkan Kinerja Guru," $J$. Pendidik. Manaj. Perkantoran, vol. 1, no. 1, pp. 94-103, 2017.

[13] S. de Vries, W. J. C. M. van de Grift, and E. P. W. A. Jansen, "Teachers' Beliefs and Continuing Professional Development," J. Educ. Adm., vol. 51, no. 2, pp. 213-231, Mar. 2013.

[14] P. Macheng, "Continuing Professional Development of Teachers in Junior Secondary Schools in Botswana," Res. Rev. J. Educ. Stud., vol. 2, no. 3

[15] N. Kirsten and W. Wermke, "Governing Teachers by Profesional Development: State Programmes for Continuing Professional Development in Sweden Since 1991," J. Curric. Stud., vol. 49, no. 3, pp. 391-411, 2017.

[16] L. H. Yuen, "The Impact of Continuing Professional Development on A Novice Teacher," Teach. Dev., vol. 16, no. 3, pp. 387-398, 2012. 